European journal of American studies

Summer 2017, including Special Issue: Popularizing

Politics: The 2016 U.S. Presidential Election

\title{
The Business of Electing a President
}

\section{Erik Hieta}

\section{(2) OpenEdition}

Journals

Electronic version

URL: https://journals.openedition.org/ejas/12123

DOI: $10.4000 /$ ejas. 12123

ISSN: 1991-9336

Publisher

European Association for American Studies

\section{Electronic reference}

Erik Hieta, "The Business of Electing a President", European journal of American studies [Online], 12-2 I

2017, document 2, Online since 02 August 2017, connection on 08 July 2021. URL: http://

journals.openedition.org/ejas/12123 ; DOl: https://doi.org/10.4000/ejas.12123

This text was automatically generated on 8 July 2021 .

Creative Commons License 


\section{The Business of Electing a President}

\section{Erik Hieta}

1 In a daring act of civil disobedience, as well as political theater, Florida postman Douglas Hughes violated America's most restricted airspace to land a gyrocopter on the lawn of the U.S. capital on April 15, 2015 and deliver 535 letters, one to each member of Congress. The letters protested the influence of big money in politics: "The unending chase for money I believe threatens to steal our democracy itself," is how Hughes formulated his argument. He went on to demand that politicians refuse to take large contributions from wealthy donors and corporations, claiming that such contributions corrupt the political process and undermine the importance of individual voters. $\mathrm{He}$ tapped into a grab bag of historical references by terming himself part P. T. Barnum (the famed $19^{\text {th }}$-century showman who founded Barnum and Bailey Circus) and part Paul Revere (who alerted the colonial militia about advancing British forces at the start of the Revolutionary War), intent on reforming the political system. ${ }^{i}$ His actions anticipated a larger movement known as "Democracy Spring," one of the largest acts of civil disobedience in recent U.S. history, in which more than 1,000 people were arrested a year later for protesting outside the Capitol Building. Hughes had wanted to participate in the demonstration, but prosecutors argued that his pretrial release for such an act of civil disobedience would turn the court "into a circus." "ii Little did Hughes or the media realize the extent to which the general anger at money in politics would play out as political theater and circus combined with reality-show entertainment in 2016.

2 This article will discuss campaign finance as a cultural phenomenon and how it became bound up with celebrity politics and popular perceptions of elitism. It will address a fundamental question: How did the rhetorical function of money become so central to the popularization of politics in the last election? In doing so, it makes the argument that cultural shifts in the way voters viewed the links between money and government account for their rejection of the political status quo. Though money and politics have gone hand in hand for a long time in American politics, the use of social media popularized the rhetoric of money as never before. The article will first call attention to the links between money and pop politics, then assess campaign finance, the growing frustration with super PACs, and the significance of economic questions for voters. 
Finally, it will address the troubling and unprecedented mixing of Donald Trump's presidency and his business, followed by some concluding comments on the broader ramifications of such a polarizing presidential election.

\section{The Uniqueness of the Election}

3 Social media and the mainstream media alike traded in sound bites and the entertainment aspects of the presidential election. Donald Trump ran his campaign like a reality TV show. As former host of The Apprentice, iii Trump knew his audience, or at least he knew the angry white, largely rural, and non-college educated voters who felt alienated by the economic and political system. With an entrance theme song titled "Money, Money, Money," The Apprentice rescued the Trump brand and made his presidential campaign possible. ${ }^{\text {iv }}$ It refurbished his image as a tough businessman who gets results. Trump Tower, the setting for the show, served as the headquarters of his presidential campaign and the place where Trump put together his new administration in the days following the election. He often referred to potential members of his administration as "the finalists" in his tweets, as if treating the transition process as a rehearsal for Season 15 of The Apprentice. ${ }^{v}$ After Ivanka Trump (also famous for her work on The Apprentice) appeared on 60 Minutes with her father Donald on November 13, 2016, journalists received a "style alert" email from her fine jewelry company stating that she had worn a $\$ 10,000$ bracelet from her collection during her father's first interview as president-elect. Previously, Ivanka had promoted the dresses and shoes she had worn on the campaign trail and at the Republican National Convention. ${ }^{\text {vi }}$ She filed at least 25 trademark registrations for her brand of clothing, cosmetics, and jewelry while her father was running for office. ${ }^{\text {vii }}$ Donald Trump stated in the same 60 Minutes interview a willingness to give up his presidential salary of $\$ 400,000$ and take a symbolic $\$ 1$ a year. He was following through on a promise made on the campaign trail to put business concerns aside while president. He would not be the first president to forego a salary: Herbert Hoover and John F. Kennedy both donated their salaries to charity. Nonetheless, Donald Trump continually faced questions about how his business concerns would impact the presidency in an election that was always about money and how it was being spent. Just how unique was such a focus on money? The uniqueness lay in the extent to which voters blamed establishment politics and turned to social media to do it.

The election turned out to be a referendum on establishment politics, with the rhetoric of money underpinning discussions and perceptions of elitism. Commentators in such general editorial magazines as The Atlantic repeatedly asked if either the Republican Party or the Democratic Party would survive the 2016 election. ${ }^{\text {viii }}$ Put in historical perspective, the phenomenon of voters reacting to perceptions of elitism is nothing new. Bill Clinton won the 1992 election by portraying George H.W. Bush as an East Coast elitist. ${ }^{\text {ix }}$ Bush had previously served as vice president for likely the most revered figure in Republican Party politics, Ronald Reagan. As a former actor, Reagan embraced the television camera to espouse simple ideas and avoid complex policy positions. Perhaps inevitably, Trump compared himself to Reagan. ${ }^{x}$ Trump's simple message of restoring America's greatness echoed Reagan's former promise to lift the nation from economic malaise. Reagan had years of political experience as the former governor of California and knew how to adopt softer tones for his message of limited government in 
a manner that brought many voters together. Trump never adopted such tones in his divisive message. Yet he was most similar to Reagan in successfully packaging his message for popular consumption. When media sites began lampooning Donald Trump, he shamed and mocked the "dishonest media," driving home his message on Twitter, in interviews, and at political rallies. ${ }^{\mathrm{xi}} \mathrm{He}$ did not invent this outrage. In Invisible Hands: The Businessman's Crusade Against the New Deal, Kim Phillips-Fine has documented a conservative backlash against labor unions, government regulation, and mainstream media bias dating back to the 1930 s. ${ }^{\text {xii }}$ Many conservative voters had long heard general accusations of corrupt big government. Likewise, the idea of a liberal media bias dates back to the late 1940s. ${ }^{\text {xiii }}$ In fact, years of seeming liberal smugness and disdain for conservative values arguably even helped create the Donald Trump phenomenon. ${ }^{\text {xiv }}$ With one of the great wish-fulfillment fantasies of American life being that of a charismatic outsider vowing to fight the corrupting influence of money in politics, comprising the subject of such popular movies as Mr. Smith Goes to Washington (1939) and its updated version Dave (1993), many voters have long been convinced of the power of one person to challenge the entrenched status quo. Such movies, however, promote idealism over pragmatism and convey the message that the right outsider can change a broken system that favors only the rich and well-connected without needing to provide concrete policy measures based on compromise and experience.

\section{Super PACs, Dark Money, and a Lack of Trust in Washington}

5 The election challenged the nominating process long overseen by the political power structure. Robert Reich, former Secretary of Labor under President Bill Clinton, suggests that, ultimately, the election was less about the triumph of hatefulness over decency than about voter anger at the shift of power away from the people and toward corporations in the last few decades. ${ }^{\mathrm{xv}}$ At the start of 2016, power brokers assumed that Democrat Hillary Clinton and Republican Jeb Bush would win the respective party nominations because both had deep bases of funders. ${ }^{\text {xvi }}$ The funding was supposed to be dominated by super PACs, political committees that can collect unlimited sums of money from corporations and individuals so long as they do not coordinate their efforts with any particular political campaign. Super PACs are largely the consequence of the 2010 Citizens United v. Federal Election Commission Supreme Court decision permitting unlimited unanimous corporate spending on political candidates and their campaigns. Popular perceptions held that billionaire donors and corporations were spending unlimited amounts of money on political messaging via super PACs and that the ultimate prize for many political hopefuls was not so much votes as the money of deep-pocketed donors. ${ }^{\text {xvii }}$ An analysis of federal campaign finance reports by the Washington Post in the spring of 2016 supported such perceptions, finding that close to half of all super PAC money had come from 50 donors and that more than $50 \%$ of such super PAC mega-donors had come from Wall Street. ${ }^{\text {xviii }}$ Much of the money funneled through super PACs for political ads came from so-called dark money groups, groups that do not have to reveal the interests behind them and that have promoted their views on everything from climate change to healthcare policy to immigration. ${ }^{\text {xix }}$ In Dark Money: The Hidden History of the Billionaires Behind the Radical Right, Jane Mayer discusses how a network of exceedingly wealthy people headed principally by Charles and David 
Koch have shifted resources and influence away from the formal Republican Party apparatus, thereby pulling it far to the right and alienating many traditional party members. ${ }^{\mathrm{xx}} \mathrm{A}$ well-documented work based on five years of research, the book provides a strong historical account of the conservative ascendancy that began in the 1980s, with donor networks increasingly working to stymie efforts at meaningful labor, finance, and tax reforms, even when such agendas have been out of step with the preferences of the majority of the American public. The efforts are not new, though. Phillips-Fine notes how the Koch brothers' father, Fred Koch, was part of a previous generation who had believed in unfettered capitalism and no government interference. ${ }^{\mathrm{xxi}}$ Gradually, though, the anti-tax, anti-regulation, anti-government rhetoric of the Republican Party became so extreme that there was no room for compromise, making it difficult for corporate leaders, politicians, and voters to reach consensus on important issues.xxii The surprise in the 2016 election is that it also prevented them from reaching consensus on an established political candidate, and in that sense such historical studies do not adequately account for the larger social and cultural context that gave rise to Donald Trump.

Many Republicans and Democrats expressed a general lack of faith in Washington and concern over the corrupting influence of money in politics. Recent scholarly studies on the election process lent support to the sentiment by arguing that Washington is no longer so much about lawmaking as about moneymaking and that the influence of special interest groups, including the bribing of politicians, is a serious problem. ${ }^{\text {xxii }}$ Conservative muckraking efforts, though far less academically rigorous, only added to this perspective. The New York Times bestsellers Extortion (2013) and Throw Them All Out (2011) by Peter Schweizer, a popular, yet highly controversial, conservative political consultant and editor-at-large for the far-right media site Breitbart News, reveal the extent to which politicians extort wealthy industries and donors. Given a platform on 60 Minutes, Schweizer talked about how politicians use donations and super PACs to bankroll lavish lifestyles, with members of Congress being exempt from insider trading laws as well as whistleblower laws. He suggested that, if anything, general perceptions of bribery and other illegal activities in Washington do not go far enough in taking into account just how much money politicians are making from insider stock tips and shady land deals. Breathlessly recounting tales of corruption and drama, books such as these treat politics as a shallow form of entertainment, rich with political intrigue seemingly happening in isolation, while not linking issues of campaign finance to deeper trends in society and to cultural changes. While certainly not everyone agrees with Schweizer's alarmist polemics, established academics have also increasingly argued that politics in Washington have become a business opportunity for both Republicans and Democrats, contributing to growing inequality of incomes between the vast majority of people and the very rich. Larry M. Bartels notes in his award-winning study Unequal Democracy: The Political Economy of the New Gilded Age (2010) that the widening gap between the rich and poor is not just the result of economic forces but of comprehensive policy choices. ${ }^{\text {xxiv }}$ Citing, for example, the Bush tax cuts of 2001 and 2003 and an inadequate minimum wage, Bartels focuses on key policy shifts, mostly instituted by Republicans, which have increasingly caused elected officials to respond to the views of the wealthy and ignore those of the poor. Numerous other recent studies have found that with millionaires dominating politics in Washington, the policymaking process is indeed skewed toward outcomes that favor the upper class. ${ }^{x x v}$ "Americans see their leaders in Washington as overpaid agents of wealthy individuals and corporations who are largely disconnected 
from the concerns of average Americans," write Wendell Potter and Nick Penniman in Nation on the Take. ${ }^{\text {xxi }}$ In a vicious feedback loop, politicians and super PACs are making money off each other and not being held accountable for the source of such money.

\section{Money and Frayed Party Politics}

7 The increasingly bitter political divide in the United States has strained both parties. The 2008 recession played a crucial role in discrediting free market capitalism and political elites. ${ }^{\text {xxvii }}$ In 2009, shortly after Barack Obama was elected president, the Tea Party was born and sold as a grassroots conservative movement. Buttressed by images of older white protesters in colonial costumes, sympathizers coalesced around the idea that big government spending was out of control. Yet its true purpose proved to be far different, with the Koch brothers, the tobacco industry, and other corporate interests having secretly planned such a "spontaneous" and "grassroots" movement in back boardrooms since the 1990s in order to promote their own corporate interests and political goals. ${ }^{x x v i i i}$ It is a telling testament to the frayed political landscape that Trump was able to tap into the anti-immigrant, racist anger of many Tea Party conservatives while still being guilty of the ideological heresy of being openly hostile to free trade (the first explicitly anti-free trade president since Herbert Hoover) and proposing large-scale government spending on infrastructure. ${ }^{\text {xix }}$ Others had trouble making their voices heard as well. In 2011, the Occupy Wall Street movement received global attention for its stark critique of economic equality. The slogan "We are the 99\%" referred to income inequality between the wealthiest $1 \%$ and the rest of the population. Yet many political leaders still did not seemingly hear the message or care. In Strangers in Their Own Land (2016), Arlie Hochschild highlights the importance of emotion in politics, not just facts and figures, by giving a voice to people in rural parts of the country struggling against stagnating wages, lack of social mobility, and an increasingly elusive American dream. Trump was an "emotions candidate," able to tap into what Hochschild calls the "deep story," Other New York Times bestsellers, such as J. D. Vance's Hillbilly Elegy (2016), Nancy Isenberg's White Trash (2016), and George Packer's The Unwinding: An Inner History of the New America (2013) all document the sense of disenfranchisement and alienation felt by the white working class. "The American dream is dead," Donald Trump told a crowd of more than 6,000 in the state of New York in April 2016. "But I'm gonna make it bigger and better and stronger than ever before,"xxxi he promised, highlighting that his campaign would not be business as usual for powerful elites.

8 The candidates often tried to disassociate themselves from established party politics. Rather than big money eroding the power of political parties, as some insiders initially predicted, ${ }^{x x x i i}$ political outsiders shifted the rhetoric of money away from Washington. Donald Trump's anti-establishment counterpart on the political left, self-proclaimed Democratic Socialist Bernie Sanders, whose wrinkled suits and uncombed hair suggested that he was too poor to be taking money, emphasized that his average campaign donation was just $\$ 27$. He used such crowdfunding practices to help fund one of the most successful grassroots campaigns in presidential election history. ${ }^{\text {xxiii }}$ His major theme was that the economic and political system are rigged in favor of corporations and the very wealthy, which struck a chord with many voters already frustrated with how the Republican and Democratic parties select nominees. ${ }^{\text {xxiv }}$ Donald 
Trump's narrative suggested that he was rich enough to not have to worry about the corrupting influence of money in politics. "I'm really rich," the billionaire real estate mogul bragged, valuing his fortune at $\$ 9$ billion as he officially entered the race for the White House. ${ }^{\mathrm{xxx}}$ The subtext to his message was that he was uniquely qualified to clean house (or "drain the swamp," as he termed it) in Washington. He too was quite involved in crowdfunding, both raising money online and even passing out cash to supporters attending his events to still emphasize that he was above the mere greedy pursuit of money. ${ }^{\text {xxxvi }}$ The logic of being too rich to be influenced by money in politics is not new: the earlier presidential candidates Mitt Romney (2012) and John Kerry (2004) were also multi-millionaires. Trump promised that he would self-fund his campaign and not be beholden to super PACs or corporations, unlike Hillary Clinton. He spent about half what Clinton did on his way to the presidency. ${ }^{\text {xxvii }} \mathrm{He}$ donated $\$ 66$ million of his own money, flew across the country in his own private jet, and used his resorts to stage campaign events, ${ }^{\mathrm{xxx} v i i i}$ ultimately making more from small donors (approximately $\$ 250$ million from donors pledging $\$ 200$ or less) than any other GOP candidate in history. ${ }^{\text {xxix }}$ Though Trump wound up embracing the donors and super PACs that he originally claimed he did not need or want (with approximately $\$ 82$ million of the $\$ 647$ million raised coming from super PACs), many voters still continued to believe that, if elected, he would make elections less reliant on big money. ${ }^{\mathrm{xl}}$ Both he and Sanders before him were able to portray Clinton, a centrist Democrat, as an elitist. Clinton had her own celebrity following, with actor George Clooney raising millions of dollars for her campaign. But it did not change public perceptions of elitism. Her fundraising operation included numerous wealthy donors who wrote seven-figure checks. ${ }^{x l i}$ Despite heavily outspending Trump on television advertising and get-out-the-vote efforts, and in spite of having the support not only of Democratic party elites but also many leading Republicans and business leaders, Clinton was never completely trusted by voters due to alleged improprieties of the Clinton Foundation.

\section{Perceptions of Money and Corruption}

9 The Clinton Foundation was strongly attacked for its fundraising tactics. Clinton generated controversy for her close financial ties to Wall Street and refusal to release transcripts of her paid speeches to Goldman Sachs and other Wall Street investment houses. ${ }^{x l i i}$ Voters already tired of experienced political candidates on both the political left and right proved ready to believe accusations that the Clinton Foundation was part of a "vast, criminal conspiracy" to monetize the White House for personal profit. xliii Modern political reportage on presidential campaigns was defined by Theodore $\mathrm{H}$. White's The Making of the President 1960, Joe McGinnis's The Selling of the President 1968, Hunter S. Thompson's Fear and Loathing on the Campaign Trail '72, and Richard Ben Cramer's What It Takes: The Way to the White House (1993), written by witnesses to history and providing behind-the-scenes accounts of life on the campaign trail. Political writers do not write such books anymore, books that humanized politics and politicians. Instead of campaign trail books, many bestsellers today appeal to a built-in audience of like-minded individuals, trading on anecdotes and "reconstructed" events that the author was not there to witness personally, more often merely reflecting the banality of political culture rather than explaining it.xliv Again one finds Peter Schweizer, whose bestselling exposé Clinton Cash: The Untold Story of How and Why Foreign Governments and Businesses Helped Make Bill and Hillary Rich (2015) follows the Clinton 
money trail to reveal possible indebtedness to foreign interests. Pushing past general assumptions that the Clintons had amassed their fortune through lucrative book deals and six-figure speaking gigs, Schweizer posits shady timber and oil deals in Columbia, million-dollar contracts awarded to donors and friends for disaster relief in Haiti, and lavish contributions from energy and defense corporations and their overseas clients, foreign corporations, and governments, with wealthy international donors expecting that Hillary Clinton would return their favors once in office. Donald Trump was quick to use the book as ammunition for his attacks on "crooked Hillary." It was adapted into a documentary produced by Trump campaign CEO Stephen Bannon. Though the book was thinly sourced and the author was even forced to admit that he had not actually been able to successfully make his case, the damage had been done. A New York Times study revealed that the FBI also used the book as evidence to launch an investigation into Hillary Clinton's relationship with donors to her family foundation eleven days before the election. ${ }^{\mathrm{xlv}}$ Her alleged improprieties with the Clinton Foundation led to perceptions of corruption among many voters, ${ }^{\text {xlvi }}$ who felt she did not have their economic interests at heart.

10 Middle-class voters voiced frustration with the fact that they have played by the rules and still fallen further and further behind economically, while political insiders seem to be gaming the system in their favor. Many frustrated voters wanted both parties to address the need for a more equitable distribution of money. In the 2016 bestseller Listen, Liberal: Or, What Ever Happened to the Party of the People?, Thomas Frank demonstrates the extent to which a form of corporate and cultural elitism has taken the place of the Democratic Party's commitment to the working class. Bill Clinton and Barack Obama helped shift power away from the people toward corporations, ${ }^{\text {xlvii }}$ while at the same time the white working class began abandoning the Democratic Party. xlviii This created an opening for Donald Trump to tap into the economic insecurity and anger of many white working-class voters with the promise that he would fix the economy and hold corporate leaders accountable for the loss of jobs. "I think that it is now absolutely clear that the Democratic Party has lost touch with its working class roots," union leader John Samuelsen told the news agency Salon in an interview. "These fissures between the working class have been exploited and blown wide open by Donald Trump. Democrats need to take a step back and ask why, with all the ridiculous things Trump said, he was ultimately more palatable to working-class trade union Democrats." $x$ lix The fact that Trump's campaign appeared so improvised and designed to shock and offend, much like a scripted reality TV show, even as it undermined and subverted Republican Party elites, only contributed to a perceived disdain by liberals for many rank-and-file voters. Trump spoke of a corrupt, elite Democratic dominance of American politics and cultivated a vision of economic prosperity. For her part, Clinton misjudged voters' economic frustrations. She made matters worse by dismissing many Trump supporters as "deplorables" rather than trying to understand their economic frustrations, even if these were expressed in misguided and inflammatory ways. Even as the media and party elites began to take Trump's message more seriously, he also had to deal with accusations of corruption.

11 Those who so diligently attacked the Clinton Foundation increasingly found themselves forced to address Trump's conflicts of interest. When Trump refused to make his tax returns public, the first presidential candidate in 40 years not to do so, speculations in the media ran rampant regarding what he might be trying to hide: that he pays an 
extremely low tax rate for such a rich man, that he has donated very little money to charity, that he is not really as wealthy as he claims, or that his foreign financial entanglements and overseas investments not only suggest a conflict of interest but also run counter to his message to "Make America Great Again" by bringing jobs back to the United States. ${ }^{1}$ He refused to meet the same transparency standards as every other recent president. ${ }^{\text {li }}$ The Trump Foundation's 2015 tax forms, released several weeks after the election, revealed that the foundation broke federal laws against self-dealing, which bars the leaders of nonprofit foundations from using charity money to enrich themselves and their family. Iii Trump also allegedly used foundation money to resolve his legal issues, such as paying a state attorney general $\$ 25,000$ to drop an investigation into his scam "university." liii Likewise, reporters discovered that Trump owed at least $\$ 100$ million to Deutsche Bank, an institution which has repeatedly clashed with U.S. regulators, tried to evade U.S. tax laws and influence government policy, and has been caught trying to manipulate markets around the world. ${ }^{\text {liv }}$ Trump will certainly be the first president to owe so much to any bank. Trump the billionaire developer has business dealings in at least 20 countries, many of which have a stake in core American geopolitical interests. ${ }^{\text {lv }}$ His financial dealings have also raised concerns about his ties to foreign governments and corporations.

\section{The Presidency as Business}

12 In the weeks after his election, Trump appeared unconcerned about the overlap between his business interests and American diplomacy. In 2000, he had told an interviewer that "I could be the first presidential candidate to run and make money on it." "vi He used the campaign as a marketing platform to promote everything from Trump steaks to his golf courses to his new Washington hotel. A report by Politico found that Trump's campaign paid his family businesses more than $\$ 8.2$ million, revealing an integrated business and political operation without precedent in national politics. . $^{\text {vii }}$ The very first day after being elected, Trump used the resources of the federal government and his position in the White House to enrich himself, advertising his numerous "properties around the globe" and promoting the business interests of the rest of the family on an official ".gov" website. Iviii The implications are enormous, given the global reach of his business holdings and the Trump brand. Less than a week after the election, he met with three Indian business partners in his office at Trump Tower to discuss a Trump-branded luxury apartment complex in Mumbai. ${ }^{\text {lix }}$ The following week, he met at the Trump International Hotel, which he leases from the federal government, with approximately 100 foreign diplomats who sipped Trump-branded champagne and heard a sales pitch about his newest hotel. ${ }^{\mathrm{lx}} \mathrm{He}$ also met with the British politician Nigel Farage, asking him to oppose offshore wind farms near his two Scottish golf courses. ${ }^{1 \times i}$ The new Philippine trade envoy to the United States is a real estate magnate engaged in building a new Trump Tower in Manila. ${ }^{\text {lii }}$ For all his talk of "draining the swamp" and returning the government to the people, and for all his admitted disgust with political insiders lining their pockets and selling out the United States to foreign countries, Trump nominated to his cabinet a number of billionaires from such Wall Street firms as Goldman Sachs and did little to dispel concerns about what actions he would take when the interests of the country diverge from the interests of the Trump Organization. 
Compounding the concerns of many political and economic experts, as president-elect he refused to sell off the most visible part of his holdings-the Trump hotels, casinos, and golf courses-and instead put the proceeds in a blind trust. He said he would turn his business over to his three eldest children to run while retaining ownership. Yet, he also hinted at appointing his daughter Ivanka to a key government position. Even without any official title, she sat in on the president-elect's initial meeting with Japanese Prime Minister Shinzo Abe, ${ }^{1 x i i}$ and she joined in conversations with the leaders of Turkey and Argentina. Potential conflicts of interest between Trump's business ventures and his presidency remain unclear. The country has never before had a president that at the same time insists on running a multinational business with foreign entanglements while his children are involved in his transition to president, but are also set to run his company once he moves into the White House. Donald Trump leases his name to hotels, condos, and golf courses all over the world (meaning that he receives a direct payment when they are built), including countries where the United States has pressing national interests. Asked about these conflicts of interest, he boasted to the New York Times about the global reach of his business, saying that "the president of the United States is allowed to have whatever conflicts he wants... the law is totally on my side, the president can't have a conflict of interest." ${ }^{x i v} \mathrm{He}$ acknowledged that his move to the Oval Office will probably enrich his family further. For example, he has actively encouraged diplomats to patronize his hotel a few blocks from the White House when in town to meet with him. While federal law does not prevent Trump and his family from benefitting financially from such actions, it is less clear whether he may be violating the emoluments clause of the Constitution, which prohibits a president from taking payments or gifts from a foreign government entity. Even if President Trump seeks no special advantages from foreign governments, to what extent will foreign government officials see an advantage in doing business with the Trump Organization, and how will this affect diplomatic relations with such countries? His holdings raise serious ethical questions about personal business impacting government business and who will pay for the security against possible terrorist attacks or other risks at his branded sites.

\section{Conclusion}

14 The rhetoric of money, who has it, and how it can disrupt the status quo greatly influenced the election. Understanding how the rhetoric of money became so significant during the election of 2016 requires a cultural studies perspective. This article has emphasized that Trump's victory had just as much to do with cultural factors as with economic factors; indeed, the election had less to do with his concrete policy proposals than with the way he attacked those in power. While the journalistic accounts of his surprising victory convey a sense of immediacy and on-the-ground reporting, and the more serious academic studies add a political science angle to discussions of money and the economy, they have not been assessed together from the standpoint of broad-based cultural narratives about changing the status quo. The sense of economic distress was underpinned by a deep-seated culture conflict, as already witnessed in the 2004 election, ${ }^{1 \times v}$ with talk then of a divide between red states and blue states, between big cities and rural areas. The culture conflict in the most recent election was accentuated by even more striking economic disparities between people in different parts of the country and between elites and the shrinking middle class. Trump 
is unique because of his lack of credentials, being the first president to have neither served in politics or the military before, and the economic uncertainty that helped fuel a unique trajectory from mere entertainment value to serious contender, from reality TV star and real estate mogul to commander-in-chief. Trump's reality TV showmanship proved that many who have felt marginalized from the mainstream were looking for easy answers from a man who could mix showbiz and politics in an overly simplistic narrative of an underdog taking on the power structure. Trump was unpredictable, but he did capture the mood of economic frustration. His campaign successfully responded to perceptions that big money has effectively undermined economic opportunity and political equality. He seemingly subverted the influence of super PACs and dark money by not playing by establishment rules. Political crowdfunding sites connected supporters and candidates like Trump as never before, making it easier for people to connect via social networks and spread his message.

Social media also alienated the broader electorate from one another. Trump's message did not appeal to many black and Latino voters, and he polled most strongly in places like the Rust Belt, where the economy was weaker. ${ }^{\text {lxvi }}$ Despite Donald Trump's scandals, the narrative of the political outsider not afraid to tell it like it is, even if in divisive and bigoted language, held fast for his base during the election. While experts could not believe people would ever buy into Trump's inflammatory message and showmanship, it turned out that the failure of thinking was not his. ${ }^{\text {lxvii }} \mathrm{He}$ never adequately responded, though, to accusations of a conflict of interest between his business holdings and initial signs that he would treat the presidency as a business. Propelled to power on a cultural narrative of change, the question regarding his economic platform is whether his presidency will be defined by an acquiescence to the demands of the Republican establishment or a renewed focus on his working-class base. To that end, the grassroots frustration with the role of money in politics may not go away after the election.

The gyrocopter pilot Douglas Hughes defended his actions in court by saying it was a "question of justice," with lawyers comparing his civil disobedience to that of Rosa Parks and the Reverend Martin Luther King, Jr. The U.S. District Court judge did not agree with the civil rights comparisons, though, dismissing his actions as merely a reckless "publicity stunt." "xviii Trump, the billionaire businessman who used the power of brand recognition and a flair for publicity stunts of his own to get elected, must now find a way to heal and unite the nation. With large segments of the electorate still bitterly divided and extremely angry with one another, and many others who chose not to vote at all, Trump's first step to "Make America Great Again" will be to successfully translate his message and agenda beyond his somewhat narrow base. Yet, he may well face a highly mobilized political backlash that will indeed disrupt politics in Washington, just not in the way he has promised. 


\section{NOTES}

i. Ben Montgomery, "Awaiting his sentence for landing on Capital lawn, gyrocopter pilot Doug Hughes still seeks campaign finance reform," Tampa Bay Times, April 15, 2016, accessed March 16, 2017, http://www.tampabay.com/news/humaninterest/awaiting-his-sentence-for-landing-oncapitol-lawn-gyrocopter-pilot-doug/2273449.

ii. Bart Jansen, "Gyrocopter pilot who landed at the capital pleads guilty," USA Today, November 20, 2015, accessed March 16, 2017, http://www.usatoday.com/story/news/2015/11/20/ gyrocopter-pilot-campaign-protest-douglas-hughes-district-court/73571784/.

iii. During many seasons of this NBC game show, which began in 2004, the winner would receive a single-year contract to run one of Trump's companies.

iv. Paul Schrodt, "Why 'The Apprentice' made Donald Trump's presidential campaign possible," Business Insider, November 8, 2016, accessed March 16, 2017, http://businessinsider.com/theapprentice-paved-way-for-donald-trump-presidential-campaign-2016-11?r=US\&IR=T\&IR=T.

v. Ben Kentish, "Donald Trump accused of treating the presidency like 'The Apprentice' after calling cabinet favourites 'the finalists," Independent, November 16, 2016, accessed March 16, 2017, http://www.independent.co.uk/news/world/americas/donald-trump-the-apprentice-uscabinet-appointments-steve-bannon-reince-priebus-a7421136.html.

vi. Elizabeth Segran, "Is It Legal for Ivanka and Donald Trump to Use the Presidency to Market Their Products?" Fast Company, November 15, 2016, accessed March 16, 2017, https:// www.fastcompany.com/3065699/election-2016/is-it-legal-for-ivanka-donald-trump-to-use-thepresidency-to-market-their-prod.

vii. Richard C. Paddock, Eric Lipton, Ellen Barry, Rod Nordland, Danny Hakim, and Simon Romero, "Potential Conflicts Around the Globe for Trump, the Businessman President," The New York Times, November 16, 2016, accessed March 16, 2017,

http://www.nytimes.com/2016/11/26/us/politics/donald-trump-international-business.html.

viii. For instance, David Frum, "The Great Republican Revolt," The Atlantic, January/February 2016, accessed March 16, 2017, https://theatlantic.com/magazine/archive/2016/01/the-greatrepublican-revolt/419118/; Molly Ball, "The Day the Republican Party Died," The Atlantic, May 4, 2016, accessed March 16, 2017, https://www.theatlantic.com/politics/archive/2016/05/the-daythe-republican-party-died/481176; David A. Graham, "Does the Democratic Party Have a Future?," The Atlantic, November 9, 2016, accessed March 16, 2017, https://www.theatlantic.com/ politics/archive/2016/11/can-the-democratic-party-survive/507116/.

ix. Donald T. Critchlow, The Conservative Ascendency: How the Republican Right Rose to Power in Modern America (Lawrence: University of Kansas Press, 2011), 237.

x. Anjali Shastry, "Trump likens himself to Reagan as a truly conservative candidate," The Washington Post, January 24, 2016, accessed March 16, 2017, http://www.washingtontimes.com/ news/2016/jan/24/donald-trump-likens-himself-ronald-reagan-truly-co/.

xi. Jeremy Diamond, "Trump launches all-out attack on the press," CNN, June 1, 2016, accessed March 16, 2017, http://edition.cnn.com/2016/05/31/politics/donald-trump-veteransannouncement/.

xii. Kim Phillips-Fein, Invisible Hands: The Businessmen's Crusade Against the New Deal (New York: W.W. Norton \& Company, 2010).

xiii. Nicole Hemmer, Messengers of the Right: Conservative Media and the Transformation of American Politics (Philadelphia: University of Pennsylvania Press, 2016).

xiv. Rob Hoffman, "How the Left Created Trump," Politico, November 20, 2016, accessed March 16, 2017, http://www.politico.com/magazine/story/2016/11/how-the-left-created-donaldtrump-214472. 
xv. Robert Reich, "Democrats once represented the working class. Not any more," The Guardian, November 10, 2016, accessed March 16, 2017, https://www.theguardian.com/commentisfree/ 2016/nov/10/democrats-working-class-americans-us-election.

xvi. Ibid.

xvii. Wendell Potter and Nick Penniman, "U.S. elections 2016: 'The system is rigged, the government coin-operated," The Guardian, April 10, 2016, accessed March 16, 2017, https:// www.theguardian.com/books/2016/apr/10/nation-on-the-take-wendell-potter-nick-pennimanextract.

xviii. Matea Gold and Anu Narayanswamy, "The new Gilded Age: Close to all super-PAC money comes from 50 donors," The Washington Post, April 15, 2016, accessed March 16, 2017, https:// www.washingtonpost.com/politics/the-new-gilded-age-close-to-half-of-all-super-pac-moneycomes-from-50-donors/2016/04/15/63dc363c-01b4-11e6-9d36-33d198ea26c5_story.html.

xix. Bill Allison, "Dark Money Dominates Political Ad Spending," Bloomberg, January 28, 2016, accessed March 16, 2017, http://www.bloomberg.com/politics/articles/2016-01-28/dark-moneydominates-political-ad-spending.

xx. Jane Mayer, Dark Money: The Hidden History of the Billionaires Behind the Rise of the Radical Right (New York: Doubleday Books, 2016).

xxi. Phillips-Fine, Invisible Hands.

xxii. Steven Pearlstein, "How Big Business Lost Washington," The Washington Post, September 2, 2016, accessed March 16, 2017, https://www.washingtonpost.com/news/wonk/wp/2016/09/02/ how-big-business-lost-washington/?hpid=hp_hp-cards_hp-card-

business\%3Ahomepage\%2Fcard\&utm_term=.806e49a3c2c8.

xxiii. See, e.g., Richard L. Hasen, Plutocrats United: Campaign Money, the Supreme Court, and the Distortion of American Elections (New Haven: Yale University Press, 2016); Raymond J. La Raja and Brian F. Schaffner, Campaign Finance and Political Polarization: When Purists Prevail (Ann Arbor: University of Michigan Press, 2015); Thomas E. Mann and Norman J. Ornstein, It's Even Worse than It Looks: How the American Constitutional System Collided with the New Politics of Extremism (New York: Basic Books, 2016); Lee Drutman, The Business of America is Lobbying: How Corporations Became Politicized and Politics Became More Corporate (Oxford: Oxford University Press, 2015); Ciara TorresSpelliscy, Corporate Citizen? An Argument for the Separation of Corporation and State (Durham, NC: Carolina Academic Press, 2016).

xxiv. Larry M. Bartels, Unequal Democracy: The Political Economy of the New Gilded Age (Princeton: Princeton University Press, 2010).

xxv. See, e.g., Nicholas Carnes, White-Collar Government: The Hidden Role of Class in Economic Policy Making (Chicago: University of Chicago Press, 2013); Jacob S. Hacker and Paul Pierson, WinnerTake-All Politics: How Washington Made the Rich Richer-and Turned its Back on the Middle Class (New York: Simon \& Schuster, 2011); Martin Gilens, Affluence and Influence: Economic Inequality and Political Power in America (Princeton: Princeton University Press, 2014).

xxvi. Wendell Potter and Nick Penniman, Nation on the Take: How Big Money Corrupts Our Democracy and What We Can Do About It (London: Bloomsbury Press, 2016), 1.

xxvii. John B. Judis, The Populist Explosion: How the Great Recession Transformed American and European Politics (New York: Columbia University, 2016).

xxviii. Jeff Nesbit, Poison Tea: How Big Oil and Big Tobacco Invented the Tea Party and Captured the GOP (New York: Thomas Dunne Books, 2016).

xxix. Theda Skocpol and Vanessa Williamson, The Tea Party and the Remaking of Republican Conservatism (Oxford: Oxford University Press, 2013).

xxx. Arlie Russell Hochschild, Strangers in Their Own Land: Anger and Mourning on the American Right (New York: The New Press, 2016), 225.

xxxi. TWC News, "The American Dream is Dead. I'm Going to Make It Bigger and Better," Trump Pence Make America Great Again 2016, April 10, 2016, accessed March 16, 2017, https:// 
www.donaldjtrump.com/media/donald-trump-the-american-dream-is-dead-im-going-to-makeit-bigger-and-bett.

xxxii. Nate Cohn, "Big Money from Super PACs is Eroding the Power of Parties," The New York Times, April 16, 2015, accessed March 16, 2017, https://www.nytimes.com/2015/04/16/upshot/ big-money-from-super-pacs-is-eroding-the-power-of-parties.html.

xxxiii. Clare Foran, “Bernie Sanders's Big Money," The Atlantic, March 1, 2016, accessed March 16, 2017, https://www.theatlantic.com/politics/archive/2016/03/bernie-sanders-fundraising/ 471648/.

xxxiv. Lauren Gambino and Amber Jamieson, “'The system is rigged': widespread dissatisfaction among US voters," The Guardian, April 13, 2016, accessed March 16, 2017, https:// www.theguardian.com/us-news/2016/apr/13/guardian-reader-callout-voter-dissatisfaction-uselection-2016.

xxxv. Dominic Rushe, “'I'm really rich': Donald Trump claims \$9bn fortune during campaign launch," The Guardian, June 16, 2015, accessed March 16, 2017, https://www.theguardian.com/usnews/2015/jun/16/donald-trump-reveals-net-worth-presidential-campaign-launch.

xxxvi. Keeton Hayes, "How Will the 2016 Election Impact Crowdfunding," Kickfurther, November 1, 2016, accessed March 16, 2017, http://info.kickfurther.com/how-will-the-2016-electionimpact-crowdfunding.

xxxvii. Jacob Pramuk, "Trump spent about half of what Clinton did on his way to the presidency," CNN, November 9, 2016, accessed March 16, 2017, http://www.cnbc.com/ 2016/11/09/trump-spent-about-half-of-what-clinton-did-on-his-way-to-the-presidency.html.

xxxviii. Bill Allison, Mira Rojanasakul, Brittany Harris, and Cedric Sam, "Tracking the 2016 Presidential Money Race,” Bloomberg, December 9, 2016, accessed March 16, 2017, https:// www.bloomberg.com/politics/graphics/2016-presidential-campaign-fundraising/; Drew Harwell and Lisa Rein, "Who's helping pay for President-elect Trump's transition effort? You are," The Washington Post, November 23, 2016, accessed March 16, 2017, https://www.washingtonpost.com/ news/powerpost/wp/2016/11/23/elizabeth-warren-wants-to-know-how-donald-trump-is-usingtaxpayer-funds-for-his-transition/?utm_term=.41c75e835ad0.

xxxix. Valentina Zarya, "Donald Trump Has Made More From Small Donors Than Any Other GOP Candidate in History," Fortune, September 9, 2016, accessed March 16, 2017, http://fortune.com/ 2016/09/19/donald-trump-small-donors/.

xl. David Levinthal, "Donald Trump Embraces Donors, Super PACs He Once Decried," Time, June 16, 2016, accessed March 16, 2017, http://time.com/4373124/donald-trump-donors-super-pacs/.

xli. Allison, Rojanasakul, Harris, and Sam, "Tracking the 2016 Presidential Money Race," Bloomberg, December 9, 2016, accessed March 16, 2017, https://www.bloomberg.com/politics/ graphics/2016-presidential-campaign-fundraising/.

xlii. Simon Head, "The Clinton System," The New York Review of Books, January 30, 2016, accessed March 16, 2017, http://www.nybooks.com/daily/2016/01/30/clinton-system-donormachine-2016-election/.

xliii. Jerome Corsi, Partners in Crime: The Clintons' Scheme to Monetize the White House for Personal Profit (Long Beach, CA: WND Books, 2016), preface.

xliv. Matt Bai, "Campaign books that help shatter our politics," Yahoo News, April 20, 2017, accessed May 2, 2017, https://www.yahoo.com/news/campaign-books-help-shatterpolitics-090024400.html.

xlv. Matt Apuzzo, Michael S. Schmidt, Adam Goldman, and William K. Rashbaum, "F.B.I.'s Email Disclosure Broke a Pattern Followed Even This Summer," The New York Times, November 2, 2016, accessed March 16, 2017, http://www.nytimes.com/2016/11/02/us/politics/fbi-james-comeyhillary-clinton-donald-trump.html.

xlvi. Daniel W. Drezner, "Why Hillary Clinton's perceived corruption seems to echo louder than Donald Trump's actual corruption," The Washington Post, September 6, 2016, accessed March 16, 
2017, https://www.washingtonpost.com/posteverything/wp/2016/09/06/why-hillary-clintonsperceived-corruption-seems-to-echo-louder-than-donald-trumps-actual-corruption/?

utm_term=.fa0a5cf63bcf.

xlvii. Robert Reich, "Democrats once represented the working class. Not anymore," The Guardian, November 10, 2016, accessed March 16, 2017, https://www.theguardian.com/commentisfree/ 2016/nov/10/democrats-working-class-americans-us-election.

xlviii. Robert Reich, "Why the White Working Class Abandoned the Democratic Party," Alternet, January 21, 2016, accessed March 16, 2017, http://www.alternet.org/economy/robert-reich-whywhite-working-class-abandoned-democratic-party.

xlix. Bob Hennelly, "The union revolt no one is talking about: This election proved that you overlook the labor movement at your own peril," Salon, November 26, 2016, accessed March 16, 2017, http://www.salon.com/2016/11/26/the-union-revolt-no-one-is-talking-about-thiselection-proved-that-you-overlook-the-labor-movement-at-your-peril/.

1. Tim Walker, “Donald Trump's tax returns explained: why won't he release them, and are they holding a 'bombshell'?" Independent, September 27, 2016, accessed March 16, 2017, http:// www.independent.co.uk/news/world/americas/us-elections/donald-trump-tax-returns-

explained-wont-release-hiding-bombshell-a7324306.html.

li. Paddock et al., "Potential Conflicts Around the Globe for Trump, the Businessman President," The New York Times, November 26, 2016.

lii. David A. Fahrenthold, “Trump Foundation admits to violating ban on 'self-dealing,' new filing to IRS shows," The Washington Post, November 22, 2016, accessed March 16, 2017, https:// www.washingtonpost.com/politics/trump-foundation-apparently-admits-to-violating-ban-onself-dealing-new-filing-to-irs-shows/2016/11/22/893f6508-

b0a9-11e6-8616-52b15787add0_story.html?tid=sm_tw\&utm_term=.924dfdb48484.

liii. Paul Waldman, “Trump's history of corruption is mindboggling. So why is Clinton supposedly the corrupt one?" The Washington Post, September 5, 2016, accessed March 16, 2017, https:// www.washingtonpost.com/blogs/plum-line/wp/2016/09/05/trumps-history-of-corruption-ismind-boggling-so-why-is-clinton-supposedly-the-corrupt-one/?utm_term=.db7a5aef4f67.

liv. Russ Choma and David Corn, "Trump Has a Conflict-of-Interest Problem No Other White House Candidate Ever Had," Mother Jones, June 1, 2016, accessed March 16, 2017, http:// www.motherjones.com/politics/2016/06/trump-german-loan-deutsche-bank.

lv. Conor Friedersdorf, "Congress is Duty-Bound to Probe Trump's Finances," The Atlantic, November 29, 2016, accessed March 16, 2017, https://www.theatlantic.com/politics/archive/ 2016/11/congress-is-duty-bound-to-probe-trumps-finances/508826/.

lvi. Jerry Useem, “What Does Donald Trump Really Want?" Fortune, April 3, 2000, accessed March 16, 2017, http://fortune.com/2000/04/03/what-does-donald-trump-really-want/.

lvii. Kenneth P. Vogel and Isaac Arnsdorf, “Trump's Campaign Paid His Businesses \$8.2 Billion," Politico, September 22, 2016, accessed March 16, 2017, http://www.politico.com/story/2016/09/ donald-trump-business-campaign-trail-228500.

lviii. Nolan D. McCaskill, "Trump transition website promotes his business brand," Politico, November 10, 2016, accessed March 16, 2017, http://www.politico.com/story/2016/11/trumptransition-website-promotes-business-brand-231173.

lix. Eric Lipton and Ellen Barry, "Donald Trump Meeting Suggests He Is Keeping Up His Business Ties," The New York Times, November 19, 2016, accessed March 16, 2017, http:// www.nytimes.com/2016/11/20/us/politics/donald-trump-pauses-transition-work-to-meet-withindian-business-partners.html.

lx. Jonathan O'Connell and Mary Jordan, "For foreign diplomats, Trump hotel is place to be," The Washington Post, November 18, 2016, accessed March 16, 2017, https://www.washingtonpost.com/ business/capitalbusiness/2016/11/18/9da9c572-ad18-11e6-977a-1030f822fc35_story.html. 
lxi. Danny Hakim and Eric Lipton, "With a Meeting, Trump Renewed a British Wind Farm Fight," The New York Times, November 21, 2016, accessed March 16, 2017, http://www.nytimes.com/ 2016/11/21/business/with-a-meeting-trump-renewed-a-british-wind-farm-fight.html.

lxii. Michael Sullivan, "Who's The New Philippine Envoy? The Man Building Trump Tower Manila," NPR, November 22, 2016, accessed March 16, 2017, http://www.npr.org/sections/ parallels/2016/11/22/502895797/whos-the-new-philippine-envoy-the-man-building-trumptower-manila.

lxiii. Cristiano Lima, "Ivanka Trump sits in on meeting with Japanese prime minister," Politico, November 17, 2016, accessed March 16, 2017, http://www.politico.com/blogs/donald-trumpadministration/2016/11/ivanka-trump-shinzo-abe-meeting-231593.

lxiv. Liam Stack, Jonah Engel Bromwich, Karen Workman, and Tim Herrera, “Donald Trump's New York Times Interview: Full Transcript," The New York Times, November 23, 2016, accessed March 16, 2017, http://www.nytimes.com/2016/11/23/us/politics/trump-new-york-timesinterview-transcript.html.

lxv. Julia Azari, “Trump's Trajectory is Unique But Contains Echoes of the Past," FiveThirtyEight, November 9, 2016, accessed March 16, 2017, https://fivethirtyeight.com/features/trumpstrajectory-is-unique-but-contains-echoes-of-the-past/.

lxvi. Jed Kolko, "Trump Was Stronger Where the Economy is Weaker," FiveThirtyEight, November 10, 2016, accessed March 16, 2017, https://fivethirtyeight.com/features/trump-was-strongerwhere-the-economy-is-weaker/.

lxvii. Michael Grunwald, "What Drove the Trumpquake," Politico, November 9, 2016, accessed March 16, 2017, http://www.politico.com/magazine/story/2016/11/donaldtrumpquake-2016-214440.

lxviii. Bart Jansen, "Gyrocopter pilot who landed on Capital lawn sentenced to 4 months in prison," USA Today, April 21, 2016, accessed March 16, 2017, http://www.msn.com/en-us/news/ us/gyrocopter-pilot-who-landed-on-capitol-lawn-sentenced-to-4-months-in-prison/ar-BBs56Ki? li=BBnbcA1.

\section{ABSTRACTS}

This article discusses campaign finance as a cultural phenomenon and how it became bound up with celebrity politics and popular perceptions of elitism. It further explores how the rhetorical function of money became so central to the popularization of politics in the last election. The central argument is that cultural shifts in the way voters viewed the links between money and government account for their rejection of the political status quo. Social media popularized the rhetoric of money as never before. The article highlights the links between money and pop politics, focusing on the uniqueness of the election; super PACs, dark money, and a lack of trust in Washington; campaign finance and the frayed nature of party politics; and general perceptions about money and political corruption. Finally, it addresses the troubling and unprecedented mixing of Donald Trump's presidency and his business and the broader ramifications of such a polarizing presidential election. 
INDEX

Keywords: campaign finance, super PAC, dark money, rhetoric of money 